УДК 81 42:37.01

10.00.00 Филологические науки

\section{КОММУНИКАТИВНЫЕ СТРАТЕГИИ ПЕДАГОГИЧЕСКОГО ДИСКУРСА: ОБЗОР РАБОТ}

Дрянгина Елена Анатольевна

к.пед.н., доцент

SPIN-код: 2322-1724

Национальный исследовательский Мордовский государственный университет им. Н. П. Огарёва, Саранск, Россия

lasina.83@mail.ru

Антропоцентрическая направленность современной лингвистики определяет центральное место человека и его речевых действий в научных исследованиях. Для учителя же речь является основным инструментом, способствующим эффективности общения, его гармонизации. Поэтому так важно в процессе педагогической коммуникации выбрать коммуникативную стратегию, которая позволит быстрее и плодотворнее достичь поставленных целей. В статье рассмотрен ряд определений коммуникативной стратегии (О.С. Иссерс, И.Н. Борисовой, Ю.В. Сорокиной, Ю.Ю. Поспеловой, О.В. Филипповой), в основе которых лежит признак целеполагания. Под коммуникативной стратегией будет пониматься комплекс речевых действий, направленный на реализацию определенной коммуникативной цели. Несмотря на то, что для педагогической коммуникации характерен определенный (хотя и достаточно обширный) круг целей, единой точки зрения относительно перечня стратегий учебнопедагогического дискурса в научной литературе на данный момент нет. Среди наиболее авторитетных, цитируемых можно выделить теории В.И. Карасика (объясняющая, оценивающая, содействующая, организующая и контролирующая стратегии), Н.А. Антоновой (императивная, информативная и коммуникативно-регулирующая стратегии), М.А. Присяжной (информативная, регулятивная и контактоустанавливающая стратегии), М.Ю. Олешкова (информационноаргументирующая, манипулятивноконсолидирующая, экспрессивно-апеллятивная и контрольно-оценочная стратегии). В статье рассматриваются цели, функции педагогического общения, обусловливающие использования данных стратегий, а также особенности их реализации

Ключевые слова: ЦЕЛЬ, КОММУНИКАТИВНАЯ СТРАТЕГИЯ, ПЕДАГОГИЧЕСКИЙ ДИСКУРС
UDC 81`42:37.01

Philological sciences

\section{COMMUNICATIVE STRATEGIES IN THE PEDAGOGIC DISCOURSE: THE OVERVIEW OF WORKS}

Dryangina Yelena Anatolievna

Cand.Ped.Sci., Associate Professor

SPIN-code: 2322-1724

Mordovian N.P. Ogaryov national research State

University, Saransk, Russia

lasina.83@mail.ru

Anthropocentric orientation of modern linguistics determines the central place of the person and speech acts in scientific research. The speech is the main tool for the teacher to promote effective communication and its harmonization. Therefore, it is important in the process of pedagogical communication to select the communication strategy that will enable faster and more productive to achieve aims. The article considers several definitions of communication strategies (O. S. Issers, I. N. Borisova, Y. V. Sorokina, Y.Y. Pospelova, O. V. Philippova), which are based on the basis of aim setting. The communication strategy will be defined as a complex of speech acts aimed at realizing a specific communicative purpose. Despite the fact that pedagogical communication is characterized by a certain (though rather extensive) range of objectives, there is not a single point of view about the list of strategies of academic discourse in the scientific literature at the moment. Among the most respected, quoted it is possible to allocate the theory of V. I. Karasik (explain, evaluate, promote, organize, and control strategies), N. A. Antonova (imperative, informative, communicative and regulating strategies), M. A. Prisyazhnova (informative, regulatory and contact-establishing strategy), M. Y. Aleshkov (information-justifying, manipulative-consolidating, expressive-appellative and monitoring and evaluation strategy). The article considers the aims, functions of pedagogical communication, which contribute the using of these strategies and peculiarities of their implementation

Keywords: PURPOSE, COMMUNICATION STRATEGY, PEDAGOGIC DISCOURSE

\title{
Doi: 10.21515/1990-4665-131-121
}


Антропоцентрическая направленность современной лингвистики определяет центральное место человека и его речевых действий для научных исследований. Активно изучаются понятия языковая личность, коммуникативная личность, средства их репрезентации, реализуемые стратегии и тактики. Использование последних, прежде всего, определяется целями и задачами, которые ставит перед собой коммуникативная личность. Так как в рамках каждого дискурса решается определенный набор задач, то и набор стратегий, используемых коммуникативной личностью в том или ином дискурсе, будет отличаться.

Целью данной статьи является обзор работ, изучающих стратегии педагогического дискурса. Круг задач, решаемых педагогом в процессе профессиональной деятельности, достаточно широк. Возможно, именно это является причиной существования разных точек зрения относительно стратегий, выделяемых в педагогическом дискурсе. Выбор необходимой стратегии определяет эффективность общения педагога с учениками.

Необходимо заметить, что в современной лингвистике представлено достаточно много точек зрения, раскрывающих суть понятия «коммуникативная стратегия». Однако в основе большинства определений лежит признак целеполагания.

Например, О.С. Иссерс под речевой стратегией понимает «комплекс действий, направленный на достижение коммуникативной цели» [3, с. 54].

Коммуникативная стратегия как совокупность речевых действий, определяемых той или иной целью, рассматривается и в характеристике И.Н. Борисовой «Коммуникативная стратегия есть способ организации речевого поведения в соответствии с замыслом, интенцией коммуникантов. В широком смысле коммуникативная стратегия понимается как сверхзадача речи, диктуемая практическими целями говорящего. ... Коммуникативная стратегия речи есть способ реализации замысла, она предполагает отбор фактов и их подачу в определенном 
освещении с целью воздействия на интеллектуальную, волевую и эмоциональную сферу адресата» [2, с. 85-86].

Подобное же определение находим и у Ю.В. Сорокиной: «коммуникативная стратегия - это комплекс речевых действий, направленных на достижение глобальной коммуникативной цели, зависящих от личности коммуникантов, отношений между ними и условий между ними. Коммуникативная цель реализуется в определенной коммуникативной (речевой) стратегии, подчиняющей себе процесс речевой коммуникации, в процессе которой автор текста решает ряд практических задач, имеющих промежуточную цель» [10, с. 89].

Ю. Ю. Поспелова также под коммуникативной стратегией понимает «творческую поэтапную реализацию коммуникантом плана построения своего речевого поведения для достижения общей языковой / неязыковой цели общения» [8, с 308].

Таким образом, коммуникативная стратегия «линия речевого поведения участника коммуникации» [12], которая направлена на реализацию коммуникативной цели.

Схоже звучит и определение коммуникативных стратегий педагогического дискурса, лишь конкретизируется ситуация общения и цели участников общения: стратегия педагогического дискурса - это «последовательность интенций речевых актов в типовой ситуации социализации. Они могут быть охарактеризованы как пояснение, объяснение нового материала, оценка результатов работы, контроль, взаимодействие и организация деятельности основных участников данного дискурса - учителя и учеников» [11].

В.И. Карасик считает, что для педагогического дискурса характерны объясняющая, оценивающая, содействующая, организующая и контролирующая стратегии [3, с. 6-15]. Этой же классификации в своих работах придерживаются А.Е. Мануилова, Ю.Ю. Поспелова, М.Н. 
Тленкопачева и др. Как правило, сочетание данных стратегий можно наблюдать на протяжении одного занятия: информирующая стратегия реализуется в процессе передачи знаний; оценивающая - при оценке работы ученика, в процессе анализа событий, персонажей, определенных обстоятельств в целом; содействующая - в поддержке ученика, корректном исправлении ошибок, организующая - в создании условий, способствующих максимально плодотворной и гармоничной совместной работе; контролирующая - в получении через обратную связь с адресатом объективной информации о том, насколько полно понят и усвоен изученный материал, достаточно ли сформированы умения и навыки.

Несколько иная классификация представлена в трудах Н.А. Антоновой [1]. Она выделяет императивную, информативную и коммуникативно-регулирующую педагогические речевые стратегии, основываясь на функциях педагогического общения. Реализацию гностической функции автор видит в информационной стратегии, организаторской - в императивной («преподаватель в своей деятельности побуждает и стимулирует слушателей к физическим и ментальным действиям, регулирует и контролирует процесс общения» [1]), конструктивной и воспитательной - в коммуникативно-регулирующей, способствующей эффективному взаимодействию учителя с учениками. При этом ведущая роль отводится императивной стратегии.

Близка к уже рассмотренной система коммуникативных педагогических стратегий, предложенная М.А. Присяжной. «В рамках дидактического целеполагания основная стратегия речевого поведения учителя - информативная». Кроме того рассматриваются регулятивная и контактоустанавливающая стратегии. Регулятивная стратегия направлена на управление деятельностью учащихся, контактоустанавливающая реализуется в поддержании эффективного контакта с учениками, повышении педагогического воздействия. 
М.Ю. Олешков в монографии «Моделирование коммуникативного процесса» [7] выделяет четыре стратегии педагогического дискурса, четко фиксируя их цели. Информационно-аргументирующая стратегия имеет интенции сообщения, трансляции, убеждения, создания общего пресуппозиционального фонда, инструктажа. В процессе реализации данной стратегии автор преследует дидактические цели, стремясь передать в интересной, доступной форме информацию, связанную с темой урока, убедить в истинности сообщаемого, аргументировать свою позицию. Интенциями манипулятивно-консолидирующей стратегии являются консолидация, управление, координация деятельности. Реализуя данную стратегию, учитель организует совместную с учениками деятельность и управляет ею. Часто за счет подчинения адресата, побуждения совершать определенные действия. «Подчинение может касаться как непосредственно предметно-манипулятивного действия, так и мыслительного процесса, личностных интенций» [7]. Автор стремится сохранить ведущую роль координатора, определяющего «права на речь». В ходе реализации экспрессивно-апеллятивной стратегии, по мнению М.Ю. Олешкова, преследуется интенция сохранение оптимальной «рабочей» атмосферы. Говорящий выражает свои «чувства, эмоции, оценки, предпочтения, настроения в отношении речевых проявлений адресата и коммуникативной ситуации в целом». При этом важной является не сама информация, а определенные мнения, планы, личностные предпочтения. Все это позволяет создать положительный эмоциональный фон, комфортную образовательную среду. Интенциями контрольнооценочной стратегии в речи учителя являются выражение собственного отношения и оценка (в том числе и на «эмоциональном» уровне) знаний учащихся, событий и ситуаций, возникающих в процессе учебной коммуникации. 
А.Р. Габидуллина [3] в ситуации педагогического общения выделяет основные эпистемические (познавательные) макростратегии и вспомогательные метадискурсивные и коммуникативнопрагматические микростратегии. Эпистемические стратегии в свою очередь делятся на нормативно-репрезентативные и проективные коммуникативные стратегии учебно-педагогического дискурса. Первые из них направлены на передачу знаний от учителя ученикам. При этом автор подчеркивает, что «образовательный процесс приобретает характер авторитарного размноживания, копирования» [3]. Правом голоса обладает только «знающий» учитель. Позиция учеников исключительно пассивно воспринимающая. В процессе реализации проективных стратегий «определенный набор понятийных представлений и языковых средств» создается в процессе совместной деятельности учителя и учеников. Метадискурсивные стратегии (конфликтные и кооперативные) являются промежуточным звеном между эпистемическими (предметными) и коммуникативно-прагматическими стратегиями, обеспечивая «понятность, нормативность, соблюдение выдерживания необходимых параметров речи (тема, громкость, четкость артикуляции, ясность изложения), регулируют ведение диалога и управление им: захват инициативы и ее отстаивание, ввод и подготовка собственных слов, прерывание, контроль внимания и понимания, исправление ошибочности и оценка избранных средств выражения, замечания по поводу речевых умений и способностей адресата, а также уместности темы, сосредоточенности на ней и учета условий протекания учебного диалога» [3]. Коммуникативнопрагматические стратегии (этикетные, императивные и оченочные) определяются соответствующей коммуникативной ситуацией, нормами речевого поведения. Их цель - регулирование эффективного межличностного взаимодействия. 
Таким образом, в силу схожести целей, на основе которых выделяются стратегии педагогического дискурса, существующие на данный момент теории имеют точки соприкосновения, схожие трактовки. Однако единой позиции относительно перечня стратегий педагогического дискурса в научной литературе на данный момент нет.

\section{Литература}

1. Антонова Н. А. Стратегии и тактики педагогического дискурса / Н. А. Антонова // Проблемы речевой коммуникации : межвуз. сб. науч. тр. - Саратов : Изд-во Сарат. ун-та, 2007. - Вып.7. - С. 230-236.

2. Борисова И. Н. Категория цели и аспекты текстового анализа / И. Н. Борисова // Жанры речи. Вып.2. - Саратов: Колледж, 1999. - С.81-96

3. Габидуллина А. Р. Педагогическая лингвистика: учебное пособие для студентов высших учебных заведений / А. Р. Габидуллина [Электронный ресурс]. Горловка: ГГПИИЯ, 2011. - Режим доступа: http://textarchive.ru/c-2245472-pall.html.

4. Иссерс О. С. Коммуникативные стратегии и тактики русской речи / О. С. Иссерс. - М.: Едиториал УРСС, 2002. - 284 с.

5. Карасик В. И. Характеристики педагогического дискурса / В. И. Карасик // Языковая личность: аспекты лингвистики и лингводидактики: Сб. науч. тр. / ВГПУ. Волгоград: Перемена, 1999. - С. 3-18.

6. Мануилова А. Е. Педагогические речевые стратегии в речевом поведении учителя (на материале художественной прозы А.П.Чехова) / А. Е. Мануилова, Л. 3. Подерезкина // Молодежный научный форум: Гуманитарные науки: электр. сб. ст. по материалам XXX студ. междунар. заочной науч.-практ. конф. - М.: «МЦНО». - 2016 -

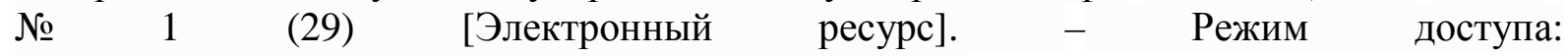
https://nauchforum.ru/archive/MNF_humanities/1(29).pdf

7. Олешков М. Ю. Моделирование коммуникативного процесса: монография / М. Ю. Олешков. - Нижний Тагил, 2006. - 336 с.

8. Поспелова Ю. Ю. Педагогический дискурс и его характеристики / Ю. Ю. Поспелова // Вестник КГУ им. Н.А. Некрасова. - 2009. - № 1. - С. 307-310.

9. Присяжная М. А. Стратегии и тактики педагогического дискурса / М. А. Присяжная // Проблемы филологии глазами молодых исследователей: Материалы конференции студентов, аспирантов и молодых ученых (апрель 2009 г.) [Электронный pecypc]. - Режим доступа: http://bookbk.net/book/45-problemy-filologii-glazami-molodyxissledovatelej-materialy-konferencii-studentov-aspirantov-i-molodyx-uchenyx-aprel-2009g/16-strategii-i-taktiki-pedagogicheskogo-diskursa.html.

10. Сорокина Ю. В. Стратегия самопрезентации как элемент эффективного речевого воздействия в рамках педагогического дискурса / Ю. В. Сорокина // Вестник Челябинского государственного университета. - 2014. - № 6 (335) Филология. Искусствоведение. - Вып. 88. - С. 89-92.

11. Тленкопачева М. Н. Основные элементы педагогического дискурса / М. Н. Тленкопачева // Актуальные вопросы филологических наук: материалы III Междунар. науч. конф. (г. Казань, октябрь 2015 г.). - Казань: Бук, 2015. - С. 57-60.

12. Филиппова О. В. Тактики косвенного речевого воздействия в структуре коммуникативной личности учителя-филолога / О. В. Филиппова, Е. В. Волгина // Политематический сетевой электронный научный журнал Кубанского 
государственного аграрного университета (Научный журнал КубГАУ). - Краснодар: КубГАУ, 2013. - № 91. - Режим доступа: http://ej.kubagro.ru/2013/07/pdf/56.pdf.

\section{References}

1. Antonova N. A. Strategii i taktiki pedagogicheskogo diskursa / N. A. Antonova // Problemy rechevoj kommunikacii : mezhvuz. sb. nauch. tr. - Saratov : Izd-vo Sarat. un-ta, 2007. - Vyp.7. - S. 230-236.

2. Gabidullina A. R. Pedagogicheskaja lingvistika: uchebnoe posobie dlja studentov vysshih uchebnyh zavedenij / A. R. Gabidullina [Jelektronnyj resurs]. - Gorlovka: GGPIIJa, 2011. - Rezhim dostupa: http://textarchive.ru/c-2245472-pall.html.

3. Issers O. S. Kommunikativnye strategii i taktiki russkoj rechi / O. S. Issers. - M.: Editorial URSS, 2002. - $284 \mathrm{~s}$.

4. Karasik V. I. Harakteristiki pedagogicheskogo diskursa / V. I. Karasik // Jazykovaja lichnost': aspekty lingvistiki i lingvodidaktiki: Sb. nauch. tr. / VGPU. - Volgograd: Peremena, 1999. - S. 3-18.

5. Manuilova A. E. Pedagogicheskie rechevye strategii v rechevom povedenii uchitelja (na materiale hudozhestvennoj prozy A.P.Chehova) / A. E. Manuilova, L. Z. Poderezkina // Molodezhnyj nauchnyj forum: Gumanitarnye nauki: jelektr. sb. st. po materialam XXX stud. mezhdunar. zaochnoj nauch.-prakt. konf. - M.: «MCNO». - 2016 - № 1 (29) [Jelektronnyj resurs]. - Rezhim dostupa: https://nauchforum.ru/archive/MNF_humanities/1(29).pdf

6. Oleshkov M. Ju. Modelirovanie kommunikativnogo processa: monografija / M. Ju. Oleshkov. - Nizhnij Tagil, 2006. - 336 s.

7. Pospelova Ju. Ju. Pedagogicheskij diskurs i ego harakteristiki / Ju. Ju. Pospelova // Vestnik KGU im. N.A. Nekrasova. - 2009. - № 1. - S. 307-310.

8. Prisjazhnaja M. A. Strategii i taktiki pedagogicheskogo diskursa / M. A. Prisjazhnaja // Problemy filologii glazami molodyh issledovatelej: Materialy konferencii studentov, aspirantov i molodyh uchenyh (aprel' 2009 g.) [Jelektronnyj resurs]. - Rezhim dostupa: http://bookbk.net/book/45-problemy-filologii-glazami-molodyx-issledovatelej-materialykonferencii-studentov-aspirantov-i-molodyx-uchenyx-aprel-2009-g/16-strategii-i-taktikipedagogicheskogo-diskursa.html.

9. Sorokina Ju. V. Strategija samoprezentacii kak jelement jeffektivnogo rechevogo vozdejstvija v ramkah pedagogicheskogo diskursa / Ju. V. Sorokina // Vestnik Cheljabinskogo gosudarstvennogo universiteta. - 2014. - № 6 (335) Filologija. Iskusstvovedenie. - Vyp. 88. - S. 89-92.

10. Tlenkopacheva M. N. Osnovnye jelementy pedagogicheskogo diskursa / M. N. Tlenkopacheva // Aktual'nye voprosy filologicheskih nauk: materialy III Mezhdunar. nauch. konf. (g. Kazan', oktjabr' 2015 g.). - Kazan': Buk, 2015. - S. 57-60.

11. Filippova O. V. Taktiki kosvennogo rechevogo vozdejstvija $\mathrm{v}$ strukture kommunikativnoj lichnosti uchitelja-filologa / O. V. Filippova, E. V. Volgina // Politematicheskij setevoj jelektronnyj nauchnyj zhurnal Kubanskogo gosudarstvennogo agrarnogo universiteta (Nauchnyj zhurnal KubGAU). - Krasnodar: KubGAU, 2013. - № 91. - Rezhim dostupa: http://ej.kubagro.ru/2013/07/pdf/56.pdf. 